УДК 378.04(477)

(C) Ворожбіт-Горбатюк В. В., Зозуля К. В., Собченко Т. М., 2021 р.

http://orcid.org/0000-0002-5138-9226

http://orcid.org/0000-0002-0697-5138

http://orcid.org/0000-0002-9213-5556

DOI 10.34142/23128046.2021.50.02

В. В. Ворожбіт-Горбатюк

К. В. Зозуля

Т. М. Собченко

\title{
НАУКОВИЙ ГУРТОК В РЕАЛІЗАЦІЇ ІДЕЇ НАВЧАННЯ ЧЕРЕЗ ДОСЛІДЖЕННЯ ЗДОБУВАЧІВ ПЕРШОГО БАКАЛАВРСЬКОГО РІВНЯ ВИЩОЇ ОСВІТИ (3 ДОСВІДУ ХНПУ ІМЕНІ \\ Г. С. СКОВОРОДИ)
}

У статті автори презентували досвід роботи наукового гуртка «Педагогічне коріння» в Харківському начіональному педагогічному університеті імені Г. С. Сковороди. Науковий гурток об'єднав студентівбакалаврів на факультеті іноземної філологіі (2001 - 2014 рр.) i на юридичному факультеті університету (2012 - 2014 рр.). Проаналізований $i$ узагальнений у статті досвід реалізує ідею навчання через дослідження. Робота координатора і членів гуртка була спрямована на формування навичок дослідника, умінь критичного мислення, академічного усного $i$ писемного мовлення, досвіду аргументувати і доводити свою позицію.

Авторами проаналізовано програма і положення про роботу наукового гуртка, звітні матеріали, результати творчих студій і науково-популярних публікачій, які підтверджують участь членів гуртка «Педагогічне коріння» в розробленні методичного забезпечення самостійної роботи здобувачів першого бакалаврського рівня вищої освіти.

У статті зазначено, щео ініціатива створення гуртка виходила від самих студентів, які зацікавилися історією педагогіки з позицій спільності форм, прийомів і методів роботи з першоджерелами з фаховою підготовкою філологів. Згодом до роботи гуртка долучилися $і$ студенти юридичного факультету. Робота наукового гуртка була спрямована на особистісне зростання студентів, системну професійну профорієнтацію.

Просвітницькі ініціативи студентів - членів гуртка передбачали адаптування наукового доробку визначних персоналій історикопедагогічного дискурсу для вчителів-практиків, батьків дітей, одногрупників, молоді, яка не має педагогічної підготовки. Гуртківиі приділяли увагу дослідженню індивідуального шляху успіху визначних педагогів. І з успіхом інтерпретували свої знахідки.

Переваги наукового гуртка в реалізачії ідеї навчання через дослідження здобувачів першого бакалаврського рівня вищої освіти: підвищення рівня 
зацікавленості педагогічними науками, системна профорієнтація, доцільна інформаційна, організачійна, методична підтримка.

Ключові слова: вища освіта, гурток, навчання через дослідження, підготовка фахівиів, педагогічний досвід, «рівний рівному», університет.

Vorozhbit-Horbatiuk V. V., Zozulia K. V., Sobchenko T. M. Scientific circuit in the implementation of the idea of learning through the research of the first bachelor's levels of higher education (H.S. Skovoroda Kharkiv National Pedagogical University experience). In the article the authors presented the experience of the scientific circle "Pedagogical Roots" at the H.S. Skovoroda Kharkiv National Pedagogical University. The research group united bachelor students at the Faculty of Foreign Philology (2001 - 2014) and at the Faculty of Law of the University (2012 - 2014). The experience analyzed and generalized in the article implements the idea of learning through research. The work of the coordinator and members of the circle was aimed at developing the skills of the researcher, critical thinking skills, academic oral and written speech, experience in arguing and proving their position.

The authors analyzed the program and regulations on the work of the scientific circle, reporting materials, results of creative studies and popular science publications, which confirm the participation of members of the circle "Pedagogical Roots" in developing methodological support for independent work of first bachelor's degree.

The article notes that the initiative to create a circle came from the students themselves, who were interested in the history of pedagogy from the standpoint of common forms, techniques and methods of working with primary sources with professional training of philologists. Later, law students joined the group. The work of the scientific circle was aimed at personal growth of students, systematic professional career guidance.

Educational initiatives of students - members of the group provided for the adaptation of scientific achievements of prominent personalities of historical and pedagogical discourse for teachers-practitioners, parents of children, classmates, young people who do not have pedagogical training. The students paid attention to the study of the individual path of success of outstanding teachers. And successfully interpreted their findings.

Advantages of the scientific circle in the implementation of the idea of education through the study of applicants for the first bachelor's degree in higher education: increasing interest in pedagogical sciences, systematic career guidance, appropriate information, organizational, methodological support.

Key words: higher education, circle, study through research, training of specialists, pedagogical experience, "equal to equal», university.

Вступ. Сьогодення життедіяльності університетів України і світу характеризується низкою трансформацій, зорієнтованих на формування фахівця-дослідника. Серед значущих аспектів цих трансформацій $є$ 
обгрунтування, реалізація, інтерпретація і логістика ідеї навчання через дослідження здобувачів вищої освіти різних рівнів.

Ідея навчання через дослідження в національних системах вищої освіти визначена ресурсом соціального прогресу, підвищенням якості університетської освіти, інструментом втілення студентоцентрованого підходу в Паризькому комюніке (Париж, 25 травня 2018 р.) (Paryzke komiunike, 2018).

Широкий загал науковців і педагогів-практиків розробляє заявлену в темі статті проблему. 3-поміж багатьох звернемо увагу на висновки i узагальнення, контекстуально близькі темі цієї статті, представлені в дослідженнях: компаративний аналіз форм, методів, способів навчання через дослідження в університетах (О. Бульвінська, 2019) (Bulvinska, 2019), ресурси творення конструктивного освітнього середовища у закладі вищої освіти (Н. Борисенко, В. Ворожбіт-Горбатюк, 2017) (Vorozhbit-Horbatiuk \& Borysenko, 2017), сутність, моделі інтеграції навчання і дослідження (Л. Козак, 2016) (Kozak, 2016).

Ретельний аналіз фактологічного матеріалу свідчить, що логістика організації навчання через дослідження - динамічне і багатофакторне явище в педагогічній інноватиці (Kozak, 2016). Затребуваними є питання ретроінновації організаційних і процесуальних компонент роботи наукових гуртків як перевіреного часом, актуального способу синтезування навчальнопізнавальних і дослідницьких комунікацій учасників освітнього процесу в університеті.

Мета та завдання.Метою цієї статті визначено: аналіз і узагальнення досвіду роботи наукового гуртка «Педагогічне коріння» в Харківському національному педагогічному університеті імені Г. С. Сковороди, факультети іноземної філології (2001 - 2014 рр.) та юридичний (2012 - 2014 рр.).

Методи дослідження. Методи і процедура дослідження: після визначення теми і мети статті було використано метод вивчення продуктів діяльності, що дозволив визначити результати навчання, які були сформовані у здобувачів - членів наукового гуртка «Педагогічне коріння», метод контент-аналізу для виявлення і оцінки особливостей і характеристик текстів, інших носіїв інформації(зокрема, - програми і положення про роботу наукового гуртка, звітні матеріали, результати творчих студій i науковопопулярних публікацій, участь членів гуртка в розробленні методичного забезпечення самостійної роботи здобувачів першого бакалаврського рівня вищої освіти). Наступний етап розроблення дослідження: аналіз, систематизація і узагальнення отриманих результатів емпіричної розвідки, формулювання висновків і визначення перспектив. 
Результати. Організація роботи студентського наукового гуртка «Педагогічне коріння» в Харківському національному педагогічному університеті імені Г. С. Сковороди під керівництвом кандидата педагогічних наук, доцента В.В. Ворожбіт витримала достатній період апробації: на факультеті іноземної філології робота гуртка була організована 32001 по 2012 рр., у 2012 р. до студентів факультету іноземної філології долучилися другокурсники юридичного факультету. Робота гуртка була призупинена наприкінці 2014 р. у зв'язку з тривалою відпусткою його організатора.

Мета діяльності гуртка «Педагогічне коріння» полягала у створенні сприятливих умов для науково-дослідницької діяльності, наукового, особистісного зростання студентів. Власне, ініціатива створення гуртка виходила від самих студентів, які зацікавилися історією педагогіки з позицій спільності форм, прийомів і методів роботи 3 першоджерелами 3 фаховою підготовкою філологів. У межах діяльності наукового гуртка студенти отримали змогу активізувати свою наукову роботу, вчасно отримувати додаткову інформаційно-методичну допомогу від викладачів ХНПУ імені Г. С. Сковороди.

Програмою роботи студентського наукового гуртка було передбачено організацію різноманітних науково-просвітницьких заходів, як-от: студентські конференції, диспути, круглі столи, наукові, методичні i популярні інформування. Значимим завданням роботи студентського наукового гуртка виступало сприяння підготовці i втіленню програми публікаційної активності студентів, виявлення і вирішення поточних питань, які виникали у студентів під час наукових розвідок.

У своїй діяльності студентський науковий гурток «Педагогічне коріння» керувався ідеями і принциповими положеннями демократичного підходу в управлінні, що забезпечувався правом голосу і членством кожного гуртківця; гуманістичного i особистісно зорієнтованого підходів, що передбачали роль організатора гурткової роботи в якості виключно координатора індивідуальних ініціатив і самостійної науково-дослідної роботи конкретного чи групи студентів; толерантності, що забезпечувалася довірою і розумінням мотивів науково-пошукової діяльності, підтримки пізнавальних інтересів кожного учасника освітнього процесу.

У Харківському національному педагогічному університеті імені Г. С. Сковороди робота студентських наукових гуртків - типове явище. Діяльнясть гуртка здійснювалася за погодженням із адміністрацією університету, педагогічним колективом факультету іноземної філології. Основною формою гурткової роботи визначено самостійну індивідуальну та/або групову роботу, індивідуальні консультації під час підготовки 
науково-популярних публікацій. Засідання наукового гуртка проходило у вільний від аудиторних занять час у різних локаціях: у парковій зоні університету і міста, в музеї університету, в залах Харківської державної наукової бібліотеки імені В.Г. Короленка, Харківському історичному музеї.

Незаперечною перевагою роботи наукового гуртка $\epsilon$ те, що студент має змогу долучитися до практично зорієнтованої профорієнтаційної роботи у напрямі академічних едукацій. Ключовим критерієм факту приналежності до діяльності гуртківців «Педагогічного коріння» була активність практичного спрямування. Так, просвітницькі ініціативи передбачали адаптування наукового доробку визначних персоналій історико-педагогічного дискурсу для вчителів-практиків, батьків дітей, одногрупників, молоді, яка не має педагогічної підготовки.

Науково-пошукова робота гуртківців передбачала вивчення не лише світового досвіду, але й актуальні критичні компаративні висновки щодо доцільності і можливих способів використання світового педагогічного досвіду в національній освітній практиці. Багато уваги студенти-гуртківці приділяли дослідженню індивідуального шляху успіху визначних педагогів. I вчилися інтерпретувати свої знахідки.

Наприклад, у 2009-2012 pp. гурток «Педагогічне коріння» ознаменувався ретельними розвідками історії і життєписів педагогів і просвітників - Г. Сковороди, М. Пирогова, К. Ушинського, А. Макаренка, В. Сухомлинського, Д. Федоренка, Ш. Амонашвілі, зокрема, їхніх студентських років. Результатом науково-пошукової роботи були презентації віднайдених фотодокументів, заміток у пресі і записів у особистих щоденниках. Гуртківці по завершенню проєкта підготували творчі роботи «Лист студентові Могилянської академії Григорію Сковороді від студента XXI століття».

Координатор гурткової роботи має бути обізнаний 3 освітньопрофесійною програмою підготовки фахівців за конкретною галуззю знань. Це допоможе налагодити гармонійну співпрацю з іншими викладачами на факультеті, розробити програму діяльності гуртківців таким чином, щоб уникнути перевантаження, а забезпечити міждисциплінарний підхід. Наприклад, в програмі роботи гуртківців «Педагогічного коріння» було започатковано і успішно реалізовано ідею інтегрування історії педагогіки, культурології і соціології. Цікавим проєктом було вивчення і представлення у короткому есе соціально-педагогічного досвіду родинного виховання власних батьків. Знаково, що ця ідея отримала розвиток. Студенти не лише аналізували виховні практики своїх родин, але й вмотивувалися досліджувати генеалогію свого роду. Виявилося, що фактично всі гуртківці мали родичів - педагогів за фахом. 
У світлі подій, що відбуваються сьогодні, досить цінним є досвід мотивування молоді бути більш уважними до родини, історії свого роду. Така обізнаність стане в нагоді при виборі професії за принципом сродності (Г. Сковорода) (Skovoroda, 2016). Достовірна інформація про пращурів ключ збереження здоров'я і душевної рівноваги.

Координатор студентиського наукового гуртка представляє інтереси учасників гурткової роботи, має працювати на факультеті. У такому випадку координування науково-дослідних проєктів буде реально можливим. Гуртківцями «Педагогічного коріння» упродовж усього періоду існування розглядалися комплексні актуальні проблеми, наприклад: культурологічні закономірності розвитку теорії і практики освітнього процесу в залежності від суспільних відносин, релігії, політичної ідеології, культури в конкретну історичну епоху; аналіз педагогічної спадщини видатних вітчизняних i зарубіжних мислителів-філологів, правознавців; розробка шляхів творчого використання педагогічно цінних знахідок у розробленні програми особистісного і професійного саморозвитку студента.

Метою конструктивної взаємодій координатора та членів гуртка були визначені актуальні і в наш час концепти організації навчання через дослідження: розширення наукового світогляду; формування умінь аналізувати, порівнювати педагогічні явища $\mathrm{i}$ факти 3 позицій ретроінновацій; розвиток критичного педагогічного мислення; створення умов для формування педагогічного світогляду. Виховна мета полягала в тому, щоб домогтися глибокого усвідомлення того, що формування високих загальнолюдських якостей особистості можливе лише через осмислення національних цінностей виховання, навчання, освіти, розвитку, відповідних родинно-побутових традицій.

Варто наголосити, що робота студентського наукового гуртка своєрідна форма організації навчальної взаємодії «рівний рівному». Це такий підхід, коли заздалегідь підготовлені студенти долучаються до організації і проведення навчально-дослідницьких дискусій, обговорення важливих тем умежах дисциплін професійного спрямування. Таким способом подана навчальна, наукова інформація завжди сприймається краще, слухачі більш відкриті. 3 іншого боку, таке активне залучення студентів до розроблення i втілення змісту робочих навчальних програм $\epsilon$ ознакою активного зворотнього зв'язку. Студенти вільні були висловлювати свої пропозиції щодо ракурсу тем викладення навчального матеріалу, забезпечення інформаційного i методичного супровіду. Сьогодні значимість такого діяльного зворотнього зв'язку важко переоцінити, напочатку 2000-них років 
то було новинкою. Тому цей аспект гурткової роботи потребує, на наш погляд, більш ретельної аналітики.

Організація роботи студентського наукового гуртка не так внутрішньо бюрократизована. Фокус роботи координатора діяльності гуртківців полягає в умінні зацікавити темою, проблемою дослідження, створити середовище, де кожен бажаючий може проявити себе не заради успішного балу, а тому що у цьому бачить свій прогрес. Тільки в останні два роки наукова і педагогічна спільнота заговорила про динамічне оцінювання здобувача вищої освіти. Динамічне оцінювання - таке, коли на кінцевий результат навчання впливають не лише якісні i кількісні показники засвоєння навчального матеріалу, а ще й прогрес у когнітивному розвитку здобувача.

Студентський науковий гурток «Педагогічне коріння» мав i використовував потенціал динамічного оцінювання - такого оцінювання, яке передбачає урахування в підсумковому оцінюванні прогресу здобувача порівняно з первинних, поточним і підсумковим оцінюванням.

Обговорення. Діяльність студентського наукового гуртка «Педагогічне коріння» в Харківському національному педагогічному університеті імені Г.С. Сковородимала позитивні наслідки для формування іміджу педагогічних дисциплін на факультеті іноземної філологї та юридичному факультеті. Гуртківці отримали корисний досвід профорієнтаційної роботи за обраною галуззю знань, випробувати сили в перших кроках наукових досліджень і презентуванні результатів науковій спільності на всеукраїнському рівні.

Продуктивним результатом діяльності гуртківців «Педагогічного коріння» за період роботи виступали: підготовка і опублікування матеріалів тез на науково-практичних конференціях, присвячених річницям від дня народження А. С. Макаренка, В. О. Сухомлинського, Г. С. Сковороди (загалом за період діяльності гуртка було оприлюднено понад 50 студентських науково-популярних публікацій), видання робочих зошитів із навчальних дисциплін «Історія педагогіки» для студентів III курсу (В. Ворожбіт, Д. Житомирський), «Порівняльна педагогіка» (В. Ворожбіт, Ю. Дмитрик), презентації матеріалів дискусійного клубу «А. С. Макаренко про роботу органів шкільного самоврядування: історія і сучасність» (А. Світлична, М. П’яткова), навчально-дослідницького проєкту «Викладач у творенні образу юридичного факультету ХНПУ імені Г. С. Сковороди», участь в університетській науковій конференції, присвяченій 120-тій річниці від дня народження А. С. Макаренка (Ю. Дмитрик, Д. Житомирський, А. Світлична). 
Студенти-гуртківці активно залучалися до обговорення питань щодо поширення ідей Болонського процесу у вищій освіті в Україні і світі. Зокрема, гуртківець Дмитро Житомирський за період роботи в гуртку підготував чотири публікації у наукових фахових виданнях із питань історії та практики організації самоврядування у вищих закладах освіти. Юрій Дмитрик підготував до друку три наукові статті з питань історії традицій козацького виховання, працював над розробкою методичного видання «Досвід викладання філологічних дисциплін у країнах Сходу». Оксана Дідик підготувала до друку дві науково-методичні статті з питань компаративних виховних практик для молодших підлітків. Катерина Зінченко (Зозуля) підготувала до друку дві статті 3 питань значення хореографії для гармонійного розвитку молодших школярів.

Висновки. На тлі дискусій (Plan diialnosti, 2020; Ukrainskivchenirealizuiutnovistandartyakademichnoiosvity, 2020; DoslidzhenniasferyosvityvUkraini, 2020) щодо проблемності реалізації ідеї навчання через дослідження варто звернути увагу, що Харківський національний педагогічний університет імені Г. С. Сковороди має цінний педагогічний досвід реалізації цієї ідеї через роботу наукових гуртків. На сьогодні кожен факультет має пропозиції долучення здобувачів усіх рівнів вищої освіти до роботи профільних гуртків за різними галузями знань i спеціалізаціями. Робота в студентському науковому гуртку не лише формує цінні компетентності дослідника, але й має очевидні перспективи щодо організації системної профорієнтації, сприяння виробленню індивідуальної траєкторії успіху здобувача-гуртківця, формування соціально значимих гнучких навичок, актуального нині емоційного інтелекту.

Перспективним напрямом уважаємо вироблення й реалізацію стратегії підтримки і стимулювання діяльності організаторів та координаторів такої гурткової роботи згідно з практикою унормування діяльності Ради молодих учених (Polozhennia pro diialnist naukovoho hurtka, 2020;Rada molodykh uchenykh Kharkivskoho natsionalnoho pedahohichnoho universytetu imeni H.S. Skovorody, 2021). Це може бути вартісною позицією в професійному рейтингу науково-педагогічного працівника, умовою подання кандидатур на професійні відзнаки. 3 контингенту здобувачів-гуртківців доцільно формувати абітурієнтське середовище для наступного рівня вищої освіти. Середовище науково-дослідної роботи гуртків може бути використане для апробації новацій методичного характеру, розгляду контраверсійних питань міждисциплінарного змісту. Гуртківці можуть активно долучатися до оновлення освітніх програм завдяки ресурсам співпраці з широким колом груп зацікавлених в якості вищої освіти осіб. Участь у гуртковій роботі може 
розглядатися як інструмент підвищення здорової конкуренції у спільності здобувачів, забезпечення академічної мобільності.

\section{ЛІТЕРАТУРА:}

Козак Л. В. Розвиток університетської освіти: навчання на основі дослідження. Освітологічний дискурс. Вип. 2(14). С. 38-52. 2016. DOI : https://doi.org/10.28925/2312-5829.2016.2.3852

Бульвінська О. Сучасні методи навчання і викладання на основі дослідження: зарубіжний досвід. Освітологічний дискурс. 2019.№ 1-2 (24-25) : DOI:10.28925/23125829.2019.1-2.83103

Ворожбіт-Горбатюк В. В., Борисенко Н. О. Конструктивне освітнє середовище у контексті сучасних новацій у вищих навчальних закладах [Електронний ресурс]. Tеорія та методика навчання та виховання. Х., 2017. Вип. 43. С. 5-14.

Дослідження сфери освіти в Україні. До більшої результативності, справедливості та ефективності (РЕЗЮМЕ3) ОГЛЯД [ Електронний ресурс ] - Режим доступу : http://documents1.worldbank.org/curated/en/790931568661644788/pdf/Overview.pdf(da та звернення 10.04.2021)

Зінченко К.В. Танці у виховних системах Стародавньої Греції. «Проблеми та перспективи розвитку педагогічних і психологічних наук»: Матер. міжнар. наук.практ. конф. (20 квітня 2013 року, м. Київ). К. : ГО «Київська наукова організація педагогіки та психології». 2013. С. 8-10.

Зінченко К. В. Теорія і практика навчання дітей молодшого шкільного віку на Україні (друга половина XX століття). Матер. IX наук.-практ. конф. молодих учених «Методологія сучасних наукових досліджень» (26-26 жовтня 2012p., м. Харків). Х. : ХНПУ імені Г.С. Сковороди, 2012. С. 26.

Паризьке комюніке, 25 травня 2018 р. [ Електронний ресурс ] - Режим доступу :https://mon.gov.ua/storage/app/media/news/Новини/2018/06/06/12/pariscommuniqueenua2018.pdf (дата звернення 10.04.2021)

План діяльності на 2020-21 рр. Еразмус+ [ Електронний ресурс ] - Режим доступу : https://erasmusplus.org.ua/zakhody/67-plan-diialnosti-neo-na-2020-r.html ） (дата звернення 10.04.2021)

Положення про діяльність наукового гуртка. Розробник: Башкір О.I. [Електронний ресурс] - Режим доступу http://hnpu.edu.ua/sites/default/files/files/Normat_dokum/Pro_diyalnist_naykovogo_gyrt ka.pdf (дата звернення 05.04.2021)

Рада молодих учених Харківського національного педагогічного університету імені Г.С. Сковороди [Електронний ресурс] - Режим доступу : http://hnpu.edu.ua/uk/division/rada-molodyh-uchenyh (дата звернення 05.04.2021)

Сковорода Григорій. Повна академічна збірка творів / За ред. проф. Леоніда Ушкалова. 2ге вид., стер. Х. : Видавець Савчук О. О., 2016. 1400 с.

Українські вчені реалізують нові стандарти академічної освіти: «Навчання через дослідження, замість відтоку мізків - циркуляція» [ Електронний ресурс ] - Режим доступу spreso.tv/news/2020/07/06/ukrayinski_vcheni_realizuyut_novi_standarty_akademichnoyi _osvity_quotnavchannya_cherez_doslidzhennya_zamist_vidtoku_mizkiv_cyrkulyaciyaq uot (дата звернення 10.04.2021)

\section{REFERENCES:}


Bashkir, O. I.(2020) Polozhennia pro diialnist naukovoho hurtka. [Position is about activity of scientific group]. _ - Retrieved form : http://hnpu.edu.ua/sites/default/files/files/Normat_dokum/Pro_diyalnist_naykovogo_gyrt ka.pdf (in Ukrainian)

Bulvinska, O. (2019) Suchasni metody navchannia i vykladannia na osnovi doslidzhennia: zarubizhnyi dosvid.

[Modern methods of studies and teaching on the basis of research: foreign experienc].

Osvitolohichnyi dyskurs.1-2 (24-25): DOI:10.28925/2312-5829.2019.1-2.83103(in Ukrainian)

Doslidzhennia sfery osvity v Ukraini. (n. d.) [Research of sphere of education is in Ukraine]. Do bilshoi rezultatyvnosti, spravedlyvosti ta efektyvnosti (REZIuME3) OHLIAD Retrieved form

:http://documents1.worldbank.org/curated/en/790931568661644788/pdf/Overview.pdf (in Ukrainian)

Kozak, L. V. (2016) Rozvytok universytetskoi osvity: navchannia na osnovi doslidzhennia». [Development of university education : studies on the basis of reseach]. Osvitolohichnyi dyskurs. 2(14). S. 38-52. DOI : https://doi.org/10.28925/23125829.2016.2.3852 (in Ukrainian)

Paryzke komiunike (2018). [Parisian communique] - Retrieved form : https://mon.gov.ua/storage/app/media/news/Новини/2018/06/06/12/pariscommuniqueenua2018.pdf (in Ukrainian)

Plan diialnosti Erazmus+.(2020) [Plan of activity of Erazmus+]. -Retrieved form : https://erasmusplus.org.ua/zakhody/67-plan-diialnosti-neo-na-2020-r.html(in Ukrainian)

Rada molodykh uchenykh Kharkivskoho natsionalnoho pedahohichnoho universytetu imeni H.S. Skovorody. (2021)[Advice of young scientists of the Kharkiv national pedagogical university of the $n$ ame of H.S. Skovoroda]. - Retrieved form : http://hnpu.edu.ua/uk/division/radamolodyh-uchenyh (in Ukrainian)

Ukrainskivchenirealizuiutnovistandartyakademichnoiosvity

[The Ukrainian scientists will realize the new standards of academic education].

"Navchannia cherez doslidzhennia, zamist vidtoku mizkiv - tsyrkuliatsiia" Retrievedform

spreso.tv/news/2020/07/06/ukrayinski_vcheni_realizuyut_novi_standarty_akademichnoyi _osvity_quotnavchannya_cherez_doslidzhennya_zamist_vidtoku_mizkiv_cyrkulyaciyaq uot (inUkrainian)

Ushkalov, L. (Ed.) (2016) SkovorodaHryhorii. [SkovorodaHryhorii]. Povnaakademichnazbirkatvoriv.2-he vyd., ster. Kharkiv : Vydavets Savchuk O. O. 1400 s. (in Ukrainian)

Vorozhbit-Horbatiuk, V. V. \& Borysenko, N. O. (2017) Konstruktyvne osvitnie seredovyshche u konteksti suchasnykh novatsii u vyshchykh navchalnykh zakladakh. [A structural educational environment is in the context of modern innovations in higher e ducational establishments]. Teoriia ta metodyka navchannia ta vykhovannia. Kharkiv. Vyp. 43. S. 5-14. (in Ukrainian)

Zinchenko, K. V. (2012) Teoriia i praktyka navchannia ditei molodshoho shkilnoho viku na Ukraini (druha polovyna XX stolittia). [Theory and practice of teaching children of junior school age in Ukraine (second half of the twentieth century)]. Mater. IX nauk.-prakt. konf. molodykh uchenykh «Metodolohiia suchasnykh naukovykh doslidzhen» (26-26 zhovtnia 2012r., m. Kharkiv). Kh. : KhNPU imeni H.S. Skovorody, S. 26. (inUkrainian)

Zinchenko, K. V. (2013) Tantsi u vykhovnykh systemakh Starodavnoi Hretsii. [Tanks in educational systems of ancient Greece].«Problemy ta perspektyvy rozvytku pedahohichnykh i psykholohichnykh nauk»: Mater. mizhnar. nauk.-prakt. konf. (20 
kvitnia 2013 roku, m. Kyiv). K. : HO «Kyivska naukova orhanizatsiia pedahohiky ta psykholohii». S. 8-10. (inUkrainian)

Інформація про авторів:
Ворожбіт-Горбатюк Вікторія Вікторівна,
ORCID: httр://orcid.org/0000-0002-5138-
9226, доктор педагогічних наук, професор,
професорка кафедри освітології та
інноваційної педагогіки Харківського
національного педагогічного університету
імені Г.С. Сковороди, вул. Валентинівська,
2, м. Харків, Україна, 61000
е-таil: gorbatykvv@ ukr.net
Зозуля Катерина Володимирівна,
ОRCID: httр://оrсіd.org/0000-0002-0697-
5138, кандидат педагогічних наук, викладач
кафедри початкової і професійної освіти
Харківського національного педагогічного
університету імені Г.С. Сковороди, вул.
Валентинівська, 2, м. Харків, Україна,
61000
е-таil: каtуsichkа89@ gтаil.сот

Собченко Тетяна Миколаївна, ORCID: http://orcid.org/0000-0002-9213-5556,

кандидат педагогічних наук, доцент, доцент кафедри освітології та інноваційної педагогіки Харківського національного педагогічного університету імені Г.С. Сковороди, вул. Валентинівська, 2, м. Харків, Україна, 61000 e-mail: sobchenkotetyana79@gmail.com

\section{Information about the authors:}

Vorozhbit-Horbatiuk Viktoriia Viktorivna, ORCID: http://orcid.org/0000-0002-51389226, Dr. hab. in Pedagogy, Professor, Professor of the Department of Educology and Innovative Pedagogy, H. S. Skovoroda Kharkiv National Pedagogical University, Valentynivska street, 2, Kharkiv, Ukraine, 61000

e-mail: gorbatykvv@ukr.net

Zozulia Kateryna Volodymyrivna, ORCID: http://orcid.org/0000-0002-0697-5138,

Candidate of Pedagogical Sciences, Ph.D, teacher of the Department of Primary and Vocational Education, H. S. Skovoroda Kharkiv National Pedagogical University, Valentynivska street, 2, Kharkiv, Ukraine, 61000

e-mail: katysichka89@gmail.com

Sobchenko Tetyana Mukolaivna, ORCID: http://orcid.org/0000-0002-9213-5556,

Candidate of Pedagogical Sciences, Ph.D, Associate Professor of the

Department of Educology and Innovative Pedagogy, H. S. Skovoroda Kharkiv National Pedagogical University, Valentynivska street, 2, Kharkiv, Ukraine, 61000. e-mail: sobchenkotetyana79@gmail.com

Цитуйте цю статтю як: Ворожбіт-Горбатюк В.В., Зозуля К.В., Собченко Т.М. Науковий гурток в реалізації ідеї навчання через дослідження здобувачів першого бакалаврського рівня вищої освіти (з досвіду ХНПУ імені Г. С. Сковороди).Теорія та методика навчання та виховання. 2021. № 50. С.19-29.

DOI: $10.34142 / 23128046.2021 .50 .02$

Дата надходження статті до редакції: 11.03 .2021 р.

Стаття прийнята до друку: 22.03.2021 p. 